\title{
Determination of allantoin in blood by high-performance liquid chromatography with pre-column derivatization
}

\author{
M. Czauderna and J. Kowalczyk \\ The Kielanowski Institute of Animal Physiology and Nutrition, \\ Polish Academy of Sciences \\ 05-110 Jablonna, Poland
}

(Received 17 October 1995; accepted 6 November 1995)

\begin{abstract}
A high-performance liquid chromatography method with pre-column derivatization for separation and quantification of allantoin in blood samples is described. Plasma after deproteinisation with trichloroacetic acid was used for the derivatization procedure. The procedure was based on allantoin conversion to glyoxylic acid which forms a hydrazone with 2,4-dinitrophenylhydrazinc. Allantoin derivatives (syn-and anti-isomers) were separated on a reversed phase column (Nova-Pak $\mathrm{C}_{18}, 4 \mu \mathrm{m}$ ) by gradient elution, and then monitored at $360 \mathrm{~nm}$. All components were completely resolved in about $46 \mathrm{~min}$. The average recovery of allantoin added to plasma samples was $101.3 \pm 8.7 \%(n=52)$. With UV detector the smallest allantoin concentration that gave reproducible integrations was $0.93 \mu \mathrm{mol} / \mathrm{l}$. The within-assay coefficient of variation $\mathrm{CV}$ for derivatization and injection was $2.7 \pm 1.2 \%$, while CV for repeated injections was $0.68 \pm 0.33 \%$. This HPLC method can also be used for determination of allantoin in urine.
\end{abstract}

KEY WORDS: allantoin, blood, determination, HPLC

\section{INTRODUCTION}

In ruminants purines are metabolized in a series of reactions to form allantoin, uric acid, hypoxanthine and xanthine. Allantoin excreted in the urine is the main end product of purine metabolism (Balcells et al., 1991; Watts, 1980) and

\footnotetext{
* Financial support from CRS grant No. 5 \$305 03307 is gratefully acknowledged
} 
originated from three possible sourcess: purine bases of rumen microorganisms, endogenous purines from tissue turnover, and feed purines. In sheep and other ruminants allantoin appears to originate predominantly from nucleic acids synthesized by rumen microorganisms (Antoniewicz et al., 1980). In ruminants there may be a close relationship between the production of microbial protein in the rumen and the excretion of purine derivatives in urine and blood. Thus, measurements of the allantoin level in blood and urine provides an indice of the amount of microbial biomass supplied to ruminants (Ryś et al., 1975; Antoniewicz et al., 1980, 1981; Lindberg et al., 1989; Chen et al., 1992). Several authors have suggested that appropriate indicator of microbial protein synthesis may be the excretion of total purine derivatives (Chen et al., 1990; Puchala et al., 1991).

One major advantage is that this approach does not require the use of an invasive method to estimate microbial protein supply. Therefore it is necessary to resolve problem of determination of allantoin level in physiological fluids (Balcells et al., 1992; Terzuoli et al., 1994, 1995). However the method based on measurements of allantoin content in urine requires a total collection of urine (e.g. 1-3 1/day for sheep) and good separation of urine from faeces is essential ( Lindberg et al., 1989; Gonda et al., 1994). Considering the above facts, it is essential to provide an accurate and selective method for the determination of allantoin in blood offering satisfactory estimation of the size of bacterial protein synthesis.

The aim of our work was to examine the suitability and accuracy of a pre-column derivatization (Young et al., 1942; Chen et al., 1993) and separation by HPLC for determination of allantoin in blood.

\section{MATERIAL AND METHODS}

\section{Reagents}

HPLC-grade methanol, acetonitrile were purchased from Merck (Darmstadt, Germany), allantoin and 2, 4-dinitrophenylhydrazine (DNPH) from Sigma (St. Louis, MO, USA). All other chemicals were of analytical reagent grade and purchased from POCH (Gliwice, Poland). Water was distilled and then deionized prior to use. HPLC-grade water was prepared using a Milli-Q system (Millipore,Toronto, Canada). Mobile phases (solvents A and B) were filtered through a $0.2 \mu \mathrm{m}$ membrane filter (Millipore). A degassing of the solvents was made by 15 min ultrasonication prior to use. 


\section{HPLC configuration}

A Waters 625 LC HPLC system (including a controller and pumps) was employed. The apparatus consisted of a turnable absorbance detector Waters Model 486, Waters 712 WISP autosampler, and computer data handling system (all equipment from Waters, Millipore, MA, USA).

Analytical method development, collection and data integration were performed by using Millennium 2001 softwarare PC-386 computer. Chromatography was carried out using a Nova-Pak $\mathrm{C}_{18}(4 \mu \mathrm{m}), 15 \mathrm{~mm} \times 183.9 \mathrm{~mm}$ I.D. (Waters, Millipore). A guard column (Waters, Millipore) of $10 \times 6 \mathrm{~mm}$ I.D. packed with reversed phase $\mathrm{C}_{18}(30-40 \mu \mathrm{m})$ pellicular packing material was used.

\section{Analytical solvents and gradient composition}

The derivatizing solution was prepared by dissolving $100 \mathrm{mg}$ of DNPH in 100 $\mathrm{ml}$ of $2 \mathrm{M} \mathrm{HCl}$ and further the obtained solution was filtered. Since the commercial DNPH contains $30 \%$ water, the actual concentration was $3.5 \mathrm{M}$. Thymol blue ( $\mathrm{pH}$ indicator) was prepared at a concentration of $0.04 \% \mathrm{w} / \mathrm{v}$.

The binary gradient program was used (Waters curvilinear program). The solvent $\mathrm{A}$ was $9 \%$ methanol in 0.01 acetic acid ( $\mathrm{v} / \mathrm{v}$ ) (adjusted with ammonia solution to $\mathrm{pH} 6.1)$ and solvent $\mathrm{B}$ was acetonitrile. The gradient used was (\% B): $0 \%$ B at $0 \mathrm{~min}, 5 \%$ at $21 \mathrm{~min}$ (concavely increased from $17 \mathrm{~min}$, line No. 7 ), $11 \%$ at $39 \mathrm{~min}$ (concavely increased, line 7), $0 \%$ at $41 \mathrm{~min}$ (linearly decreased from 39 min, line No. 6) and $0 \%$ at $47 \mathrm{~min}$ (line 11). Flow rate was $1 \mathrm{ml} / \mathrm{min}$ (the system presure $2150 \pm 40 \mathrm{psi}$ ). Injection volume was $10 \mu \mathrm{l}$. Detector was set at UV with an attenuation of 0.050 a.u.f.s., time was $47 \mathrm{~min}$. All separation was performed at room temperature. To provide calibration for blood samples, a set of allantoin standards $(6.7-401.6 \mu \mathrm{mol} / \mathrm{l})$ was used.

\section{Blood samples preparation}

Blood samples from jugular vein of sheep were collected into tubes containing heparin and centrifuged at $1500 \mathrm{~g}$ for $20 \mathrm{~min}$. The plasma was stored at $20^{\circ} \mathrm{C}$. On the day of analysis, $0.5 \mathrm{ml}$ of plasma was deproteinized with $0.5 \mathrm{ml}$ of $10 \%(\mathrm{w} / \mathrm{v})$ trichloroacetic acid and centrifuged at $10000-12000 \mathrm{rpm}$ for $15 \mathrm{~min}$. The supernatant was used for the derivatization procedure.

\section{Derivatization procedure}

A $500 \mu \mathrm{l}$ sample of deproteinized plasma or allantoin standards and $50 \mu \mathrm{l}$ of the $\mathrm{pH}$ indicator were pipetted into a centrifuge tube. To plasma samples $280 \mu \mathrm{l}$ 
of $0.6 \mathrm{M} \mathrm{NaOH}$ was added while to allantoin standards $100 \mu \mathrm{l}$ of $0.6 \mathrm{M} \mathrm{NaOH}$ only. The mixture could be stored at about $-10^{\circ} \mathrm{C}$ if necessary. After heating at $85^{\circ} \mathrm{C}$ for $60 \mathrm{~min}, 200 \mu \mathrm{l}$ of the DNPH solution was added. Next, a sample was filtrered through $0.2 \mu \mathrm{m}$ filter (Cole Parmers) into the autosampler vial.

\section{RESULTS AND DISCUSSION}

The major analytical problem in the present work was obtaining a suitable separation of allantoin-deriving products from the interfering compounds. The derivatization procedure, however is not specific due to interference by 2, 4-dinitrophenylhydrazone of other keto-acids in plasma samples. Moreover, plasma contain several components with a similar high polarity and UV absorption. To omit these problems the method was improved.

The effect of different mobile phases composition and applied gradient in the separation of allantoin derivatives (i.e. syn and anti isomers: allantoin-A and allantoin-B peaks) is shown in Figure 1. As can be seen from the chromatograms in Figure 1a and 1c, plasma samples contain peaks (I and II) of unidentified DMPH complexes that had areas comparable to those of allantoin derivative peaks (A, B). The unidentified substances are presumablly hydrazones of other keto-acids (Chen et al., 1993). As expected, the improved HPLC method enabled suitable separation of analytical peaks of allantoin A and B. Indeed, the peaks $A$ and $B$ were distinct from interfering substances in plasma, so, their presence do not affect the determination of allantoin.

Although no reduction in a area of peak A or B was observed, the increase in a peak area of a unidentified compound (I) (the retention time of $15.2 \pm 0.4 \mathrm{~min}$; Figure 1a) was found (Table l) when the processed plasma samples were stored for 3 days at room temperature.

The peaks $A$ and $B$ had a retention time of $18 \pm 2$ and $43 \pm 2$ min (mean \pm SD of 90 samples), respectively. The ratio of allantoin-B/A peak area was constant at $3.406 \pm 0.196$ (calculation based on 60 samples), irrespective of the concentration of allantoin and type of sample. Obviously, peaks A and B were suitable for quantitative determination of the unknown, although the larger peak A was preferred since more precise and accurate results were achieved. Thus, all determinations of allantoin concentration were based on allantoin-A peak.

Accuracy of the method was assessed by examining the recovery of known quantities (27.0-229.7 $\mu \mathrm{mol} / \mathrm{l})$ of allantoin added to plasma samples and was on the average $101.2 \pm 8.7 \%$ (Table 2 ) .

The relationship between the concentration (y) and allantoin-A peak area $\left(\mathrm{S}_{\mathrm{N}}\right)$ was linear over a wide range of allantoin content (6.7-401.6 $\left.\mu \mathrm{mol} / \mathrm{l}\right)$ 


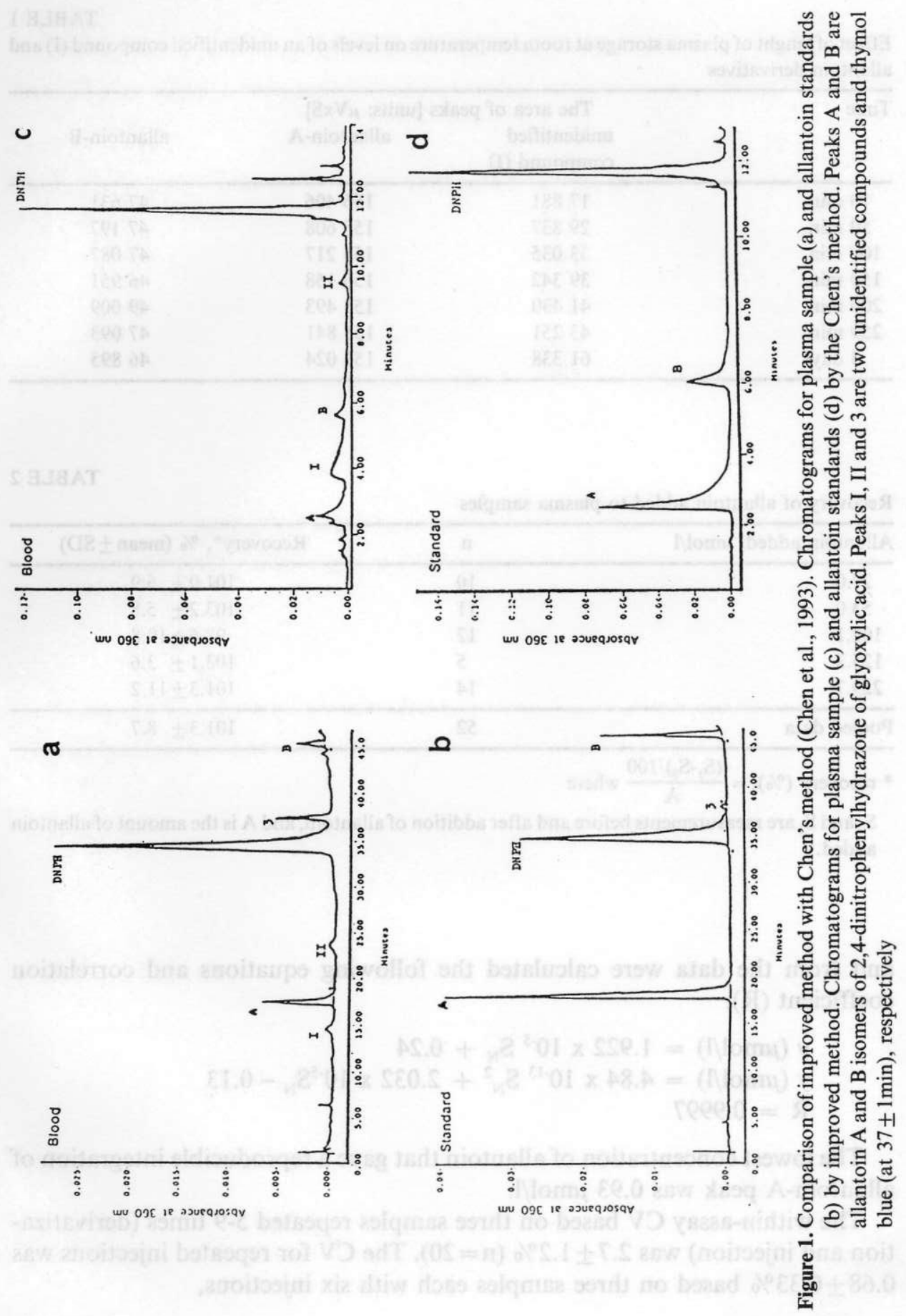


TABLE 1

Effect of lenght of plasma storage at room temperature on levels of an unidentified compound (I) and allantoin derivatives

\begin{tabular}{rccc}
\hline Time & \multicolumn{2}{c}{$\begin{array}{c}\text { The area of peaks [units: } \mu \mathrm{VxS} \text { ] } \\
\text { unidentified } \\
\text { compound }(\mathrm{I})\end{array}$} & $\begin{array}{c}\text { allantoin-A } \\
\text { allantoin-B }\end{array}$ \\
\hline $10 \mathrm{~min}$ & 17881 & 156406 & 47631 \\
$50 \mathrm{~min}$ & 29837 & 155608 & 47197 \\
$100 \mathrm{~min}$ & 33035 & 155217 & 47087 \\
$150 \mathrm{~min}$ & 39342 & 155158 & 46951 \\
$200 \mathrm{~min}$ & 41430 & 155493 & 49009 \\
$250 \mathrm{~min}$ & 43251 & 155841 & 47093 \\
3 days & 61338 & 158024 & 46895 \\
\hline
\end{tabular}

TABLE 2

Recovery of allantoin added to plasma samples

\begin{tabular}{lcc}
\hline Allantoin added, $\mu \mathrm{mol} / 1$ & $\mathrm{n}$ & Recovery*, \% (mean $\pm \mathrm{SD})$ \\
\hline 27.0 & 10 & $101.9 \pm 6.9$ \\
53.0 & 11 & $103.2 \pm 5.8$ \\
102.1 & 12 & $98.6 \pm 10.8$ \\
125.3 & 5 & $103.1 \pm 3.6$ \\
229.7 & 14 & $101.3 \pm 11.2$ \\
\hline Pooled data & 52 & $101.3 \pm 8.7$ \\
\hline
\end{tabular}

* recovery $(\%)=\frac{\left(S_{1}-S_{0}\right) / 100}{A}$ where

$S_{0}$ and $S_{1}$ are measurements before and after addition of allantoin, and $A$ is the amount of allantoin added.

and from the data were calculated the following equations and correlation coefficient $(\mathrm{R})$ :

$$
\begin{aligned}
& \mathrm{y}(\mu \mathrm{mol} / \mathrm{l})=1.922 \times 10^{-5} \mathrm{~S}_{\mathrm{N}}+0.24 \\
& \mathrm{y}(\mu \mathrm{mol} / \mathrm{l})=4.84 \times 10^{-13} \mathrm{~S}_{\mathrm{N}}{ }^{2}+2.032 \times 10^{-5} \mathrm{~S}_{\mathrm{N}}-0.13 \\
& \mathrm{R}=0.9997
\end{aligned}
$$

The lowest concentration of allantoin that gave a reproducible integration of allantoin-A peak was $0.93 \mu \mathrm{mol} / 1$.

The within-assay CV based on three samples repeated 5-9 times (derivatization and injection) was $2.7 \pm 1.2 \%(\mathrm{n}=20)$. The $\mathrm{CV}$ for repeated injections was $0.68 \pm 0.33 \%$ based on three samples each with six injections. 


\section{CONCLUSION}

The present method is highly selective for allantoin, and offers the necessary sensitivity to permit the determination of allantoin in blood samples. Obviously, this HPLC method can also be used for determination of allantoin in urine. The chromatographic separation uses a widely available a reversed-phase $C_{18}$ column. Due to the complete separation of allantoin derivatives, the proposed method has advantages over Chen's method (Chen et al., 1993). The allantoin derivatives are stable, however, increase of concentrations of some unidentified compounds was observed when the processed blood samples were stored for 3 days at room temperature. Thus, plasma samples should be subjected to chromatographic separation no later than after 3 days storage at room temperature following the derivatization procedure.

The run time of $46 \mathrm{~min}$ appears long, but information provided by plasma samples are worth the effort. Indeed, application of this HPLC method in the study of purine metabolism should provide further evidence of the influence of nutritional manipulation on microbial supply protein to the small intestine.

\section{REFERENCES}

Antoniewicz A. M., Heinemann W. W., Hanks E. M., 1980. The effect of changes in the intestinal flow of nucleic acids on allantoin excretion in the urine sheep. J. Agric. Sci., Camb. 95, 395-400

Antoniewicz A.M., Heinemann W.W., Hanks E.M., 1981. Effect of level of feed intake and body mass on allantoin excretion and the allantoin to creatinine ratio in the urinc of shecp. Rocz. Nauk. Zoot. 8, 49-65

Balcells J., Guada J. A., Castrillo C., Gasa I., 1991. Urinary excretion of allantoin and allantoin precursors by sheep after different rates of purine infusion into the duodenum. J. Agric. Sci., Camb. 116, 309-317

Balcells J., Guada J. A., Peiro J. M., Parker D. S., 1992. Simultaneous determination of allantoin and oxypurines in biological fluids by high-performance liquid chromatography. J. Chromatogr. $575,153-157$

Chen X. B., Chen Y. K., Franklin M. F., Ørskov E. R., Shand W. J., 1992. The effect of feed intake and body weight on purine derivative excretion and microbial protein supply in sheep. J. Anim. Sci. 70, 1534-1542

Chen X.B., Kyle D. J., Ørskov E. R., 1993. Measurement of allantoin in urine and plasma by high-performance liquid chromatography with pre-column derivatization. J.Chromatogr. 617, $241-247$

Chen B. X., Mathieson J., DeB Hovell F. D., Reeds P. J., 1990. Measurement of purine derivatives in urinc of ruminants using automated methods. J.Sci. Food Agric. 53, 23-33

Gonda H. L., Lindberg J. E., 1994. Evaluation of dietary nitrogen utilization in dairy cows based on urea concentrations in blood, urine and on urinary concentration of purine derivatives. Acta Agric. Scand. Sect. A 44, 1-10 
Lindberg J. E., Bristav H., Manyenga $\Lambda$. R., 1989. Excretion of purines in the urine of sheep in relation to duodenal flow of microbial protein. Swedish J. Agric. Res. 19, 45-52

Lindberg J. E., Jansson C., 1989. A rapid automated analysis of allantoin in ruminant urine. Swedish J. Agric. Res. 19, 163-167

Puchała R., Kulasek G. W., 1992. Estimation of microbial protein flow from the rumen of sheep using microbial nucleic acid urinary excretion of purine derivatives. Can. J. Anim. Sci. 72, 821-830

Ryś R., Antoniewicz. J., Maciejewicz. J., 1975. Allantoin in urine as an index of microbial protein in the rumen. Tracer Studies on Non-Protein Nitrogen for Ruminant. International Atomic Agency, Vienna, pp. 95-98

Watts R. W. F., 1980. Biochemical aspects of nucleic acid metabolism. EAAP, Publication $\mathrm{N}^{0} 27$, 106-117

Terzuoli L., Pizzichini M., Arezzini L., Pandolfi M.L., Marinello E., Pagani R., 1994. Separation and determination of allantoin, uric acid, hydantoin and urea. J. Chromatogr. 684, 350-353

Terzuoli L., Pandolfi M., Arezzini L., Pizzichini M., Marinello E., Pagani R., 1995. Scparation and determination of liver uric acid and allantoin. J. Chromatogr. 663, 143-147

Young F. G., Conway C. F., 1942. On the estimation of allantoin by the Rimini-Schryver reaction. J. Biol. Chem. 142, 839-853

\section{STRESZCZENIE}

\section{Oznaczanie allantoiny we krwi metodą IIPLC po wstępnym przeprowadzeniu jej w pochodną}

Opisano metodę oznaczania allantoiny wc krwi przy użyciu zestawu HPLC, po przeprowadzeniu jej w związek pochodny, pozwalającą na rozdzielenic od substancji interferujacych. Allantoinę w odbiałc zonym kwasem trójchlorooctowym osoczu krwi przeprowadzono w jej pochodną - kwas glikosalowy, tworzący z kolei hydrazon z 2, 4-dinitrofenylohydrazyną. Tę pochodną allantoiny (syn i anty izomery) rozdziclono na kolumnie $z$ odwróconą fazą (Nova-Pak $C_{18}, 4 \mu \mathrm{m}$ ) poprzez elucję gradientową i monitorowanie przy $360 \mathrm{~nm}$. Czas rozdzialu wszystkich składników wynosił około 46 min. Odzysk allantoiny dodanej do osocza wynosil $101.3 \pm 8,7 \%(n=52)$. Najmniejsze stężenie allantoiny pozwalające na powtarzalną integrację wynosito $0,93 \mu$ mola/1. Współczynnik zmienności wyników analizy $(\mathrm{CV})$ w obrębie przeprowadzania w pochodne i iniekcji prób wynosil $2,7 \pm 1,2 \%$, podcras gdy CV dla powtórzeń iniekcji wynosił $0,68 \pm 0,33 \%$. Metoda ta możc sluźyć także do oznaczania allantoiny w moczu. 